Hussein Bougsiaa

Institute of Pedagogy, University of Gdansk

\title{
Masculinity and the social violence against women
}

Men's violence against women and persons of lesbian, gay, bisexual, and transgender (LGBT) identity is a phenomenon that is rarely discussed in the mainstream media except in its most horrendous and sensational forms. Even rarer is a discussion of the existence of a culture of masculinity in U.S. society that for example condones and in large part perpetuates men's violence against women and LGBT persons. In the media, men's violence is invisible or assumed as "natu$\mathrm{ral}^{\prime \prime}$ and thus inevitable. While the media's debate on masculinities and violence has been relatively silent or superficial, the scholarly debate on men's violence is vibrant, and a growing men's movement is challenging misogynistic discourses and violent aspects of masculine cultures.

There has been a scholarly debate on the cause of men's gendered violence, which was made visible by feminist scholars in the twentieth century. Several popular explanations of men's violence against women have been delegitimized for their essentialization of men and masculinities. For example, sociobiologists make no distinction between men's gender and sex, arguing that men's biological sex makes men's violence against women an inevitable aspect of their social behavior (Brownmiller, 1975). Sociobiological theories present masculinity as a static monolith; however, not all men rape, and masculinities vary intra and inter-culturally. Although men are viewed to be prone to violence because of biological impulse(s), Michael Kaufman claims that there is "no psychological, biological, or social evidence to suggest that humans [i.e., men in sociobiological theories] are not predisposed to aggression and even violence" (Kaufman 2007, p. 35). Thus, evidence of the theoretical inadequacies in biological reductionism to explain men's violence is increasingly apparent. Sociobiological arguments are less prominent in the literature to date, but current theories such as Connell's hegemonic masculinity and Kimmel's entitlement theories are problematic as well.

R.W. Connell's theory of hegemonic masculinity assumes that masculinities are structured in a form of hierarchy, with "hegemonic" masculinities dominating "complicit" and "dominated" masculinities and all "empathized" femininities. This theory is rooted in structural Marxist theory and presents masculinity as a categorical and structured phenomenon (Connell, 1987). 
There has even been quantitative work that empirically "validates" Connell's hegemonic masculinity (Lusher and Robins 2010, pp. 22-30). However, Victor J. Seidler criticizes the theory of hegemonic masculinity because it does not consider how specific groups or individual men interact and negotiate with dominate discourses of masculinity. There is little emphasis on the possibility of men becoming "emotionally or psychologically damaged" by performing hegemonic masculinity in Connell's theory. Hegemonic masculinity explains very little about men's violence against women and other men, except in the vague terminology of "maintaining dominance". Thus, it poses masculinities as the problem that needs to be deconstructed; there is no place for reconstituting masculinities through discourse as a potential solution for ending men's violence against women and LGBT individuals (Seidler 2006, pp. 36-37). The reconciliatory process is indeed important to consider, as it may be an important strategy for ending all forms of men's violence. Another problematic aspect of Connell's theory is that it has been applied to two various cultural contexts without culture-specific modifications and it is assumed a universal theory of masculinity and power.

Michael Kimmel critiques and reworks the theorizing of power maintenance that liberal feminists in addition to radical ones developed to explain men's violence against women. While men's violence against women and LGBT persons as the ultimate form of violent masculinity is viewed as a drive for domination, control, and power over women and other marginalized groups, Kimmel notes that most men do not feel individually powerful, and this shows the analytical limitations of the power maintenance theories of men's violence. He does not deny that men are collectively dominant, vis-à-vis over women and "deviant" masculinities. Therefore, Kimmel theorizes that masculinity is not "the experience of power; it is the experience of [the] entitlement to power" (Kimmel 2007, pp. 100-101). Kaufman builds upon Kimmel's theory of entitlement by arguing that men's violence forms a triad: violence against women, other men, and the self. Each corner of the triad reinforces the other. Thus, the links must all be severed to address properly men's violence and hyper-masculine performance (Kaufman 2007, pp. 44-50). Kaufman rightly asserts that men must rely upon other men for emotional support (a new form of consciousness-raising) to sever the links of the triad of men's violence (Kaufman 2007, pp. 50-53). Both Kimmel's and Kaufman's theories make great leaps forward in the theoretical development of the literature on men's violence. However, they present masculinity as a monolith, with developed, western masculinity as the core model of masculinity, ignoring the various ways men and women negotiate with the dominant discourses of masculinities across cultures, especially in non-western cultures. Further, their theories cannot explain why many men do not feel entitled or seek hegemonic masculine dominance. It is time for a theory that recognizes as well the multiplicities and fluidity of masculinities, their intra- and inter-cultural variations.

Men's negotiation and reconciliation with the dominant discourses and images of masculinity bring the need for a new theorizing of masculinities to the table. Masculinities are diverse, contextual, and fluid; men's negotiations with these 
discourses vary even further. The literature needs a theory that explains why some men are able to resolve their differences with the dominant discourses of masculinity, while others use illegitimate means such as gender violence to realize their internalized depiction of masculinity. This theory must also account for the diverse discourses and images of masculinities and their positioning in myriad contexts. Therefore, being cognizant of the criticism of monolithically theorized masculinity, we must turn to a theory that I call the relative deprivation of masculinities. Laura' acknowledges that the theory of relative deprivation has merit in the study of gender violence, which I further develop to consider its usefulness in the study of men, masculinities, and violence (O'Toole 2007, pp. 77-78). Edwin Schur has applied the theory of relative deprivation to study the phenomenon of inequality and gender violence (Schur 2007, pp. 92-93). However, there has been little research that considers the explanatory power of a masculine relative deprivation, vis-à-vis male violence in a variety of contexts and cultures.

Gender-based violence is perhaps the most widespread and socially tolerated of human rights violations. It both reflects and reinforces inequities between men and women and compromises the health, dignity, security and autonomy of its victims (United Nations Population Fund 2005, p. 65).

Agencies of the United Nations have declared in many documents and forums that violence against women is an obstacle to the achievement of the objectives of equality, development and peace. As such, women's vulnerability to violence violates and impairs enjoyment of their human rights and fundamental freedoms (www.un.org/womenwatch). It has been described by the Secretary-General of the $\mathrm{UN}$ as the most shameful human rights violation and perhaps the most pervasive (UNIFEM 2003, p. 8).

Decades of research and action have led to a deeper understanding of the multifaceted nature of male violence directed at women. Such acts of violence encompass human rights, health, criminal justice, economic, and social justice dimensions. However, the prevalence and breadth of women's experiences of male violence are only gradually becoming known. The World Bank estimates that, globally, violence causes more ill-health for women than malaria and traffic accidents combined, and that it is equally serious in causing death and incapacity among women of reproductive age as cancer (Amnesty International 2006, Campbell 2002). The direct and indirect economic consequences of violence against women, both at an individual and a societal level, are beginning to be documented (see e.g. Katz 2006).

Violence against women takes many forms. The 1993 United Nations Declaration on the Elimination of Violence against Women was the first document providing an internationally agreed definition of violence as it pertains to women's experiences. Violence was defined as any act that results in, or is likely to result in, physical, sexual, or psychological harm or suffering to women, including threats of such acts, coercion or arbitrary deprivation of liberty, whether occurring in public or private life. Around the world, women suffer intimate partner violence, marital rape, rape by other men known to them and by strangers, incest, feticide, sexual 
harassment, trafficking for the purposes of forced labor or prostitution, dowry-related violence, honor killings, other forms of femicide, acid attacks, and female genital mutilation. These acts are considered to be "gender-based" violence because they are committed almost exclusively by men against women, and are supported by gender inequalities at the societal level (Ellsberg, Heise 2005; Murnen, Wright, Kaluzny 2002; Levinson 1989, Lewis 2005). Individual acts of violence are supported overtly or tacitly by cultural, social or religious norms and economic inequalities, which can serve to undermine legal prohibitions against such acts. The term "gender-based violence" underscores the links between women's social and economic status and their vulnerability to male violence.

\section{Social model of understanding men's violence against women}

Here is a paradigm shifting perspective on the issues of gender violence, sexual assault, domestic violence, relationship abuse, sexual harassment, and the sexual abuse of children. This whole range of issues I shall refer to as "Gender Violence Issues", have been seen as women's issues that some good men help out with, but I think there is a problem with this framing and I do not think it is adequate. I do not see these as women's issues that some good men help with. In fact, I am going to argue that these are primarily men's issues.

Obviously, they are also women's issues, as by calling them gender violence the women's issue is part of the problem, for a number of reasons. The first is that it gives men an excuse not to pay attention. Many men hear the term "women's issues" and we tend to tune out on this, and we think "Hey, I'm a guy. That's for the girls" or "That's for the women". In addition, many men literally as a result do not go beyond the first sentence. It is almost like a chip in our brain is activated, and the neural pathways take our attention in a different direction when we hear the term "women's issues". This is also true, by the way, of the word "gender", because many people hear the word "gender" and they think it means "women". Therefore, they think that gender issues are synonymous with women's issues. There is some confusion about the term gender.

Actually, it is worth illustrating this confusion by way of analogy. So let us think for a moment about race. For example in the U.S., when they hear the word "race", many people think that this refers to African-Americans, Latinos, AsianAmericans, Native Americans, South Asians, Pacific Islanders, on and on. Many people, when they hear the word "sexual orientation" think it means gays, lesbians, bisexuals. Moreover, many people, when they hear the word "gender", think it means women. In each case, the dominant group is not paid attention to it. It is as if white people do not have some sort of racial identity or do not belong to some racial category or construct, and as if heterosexual people do not have a sexual orientation, as if men do not have a gender. This is one of the ways that dominant systems maintain and reproduce themselves - which is to say the domi- 
nant group is rarely challenged to even think about its dominance, because that is one of the key characteristics of power and privilege, the ability to go unexamined, lacking introspection, in fact being rendered invisible in large measure in the discourse about issues that are primarily about us. Moreover, it is amazing how this works in domestic and sexual violence, how men have been largely erased from so much of the conversation about a subject that is centrally about men.

Moreover, here arises a very interesting illustration - the exercise that illustrates, at the sentence structure level, how the way that we think, literally, the way that we use language, actually conspires to keep our attention away from men. This refers to domestic violence in particular, but you can plug in other analogies. It is a work of the feminist linguist Julia Penelope.

It starts with a very basic English sentence: "John beat Mary". John is the subject. Beat is the verb. Mary is the object. Now we move to the second sentence, which says the same thing in the passive voice. "Mary was beaten by John". Now a whole lot has happened in one sentence. We have gone from "John beat Mary" to "Mary was beaten by John". We have shifted our focus in one sentence from John to Mary, and you can see John is very close to the end of the sentence, close to dropping off the map of our psychic plain! In the third sentence, John is dropped, and we have, "Mary was beaten", and now it's all about Mary. We are not even thinking about John. It is totally focused on Mary. Over the past generation, the term we have used synonymous with "beaten" is "battered", so we have "Mary was battered". And the final sentence in this sequence, flowing from the others, is, "Mary is a battered woman". So now, Mary is much identified, Mary is a battered woman is what was done to her by John in the first instance. Nevertheless, I have demonstrated that John has long ago left the conversation.

Those of us who work in the domestic and sexual violence field know that victim blaming is pervasive in this realm, which is to say, the blaming is frequently directed toward the person to whom something was done rather than the person who did it. In addition, we say things like, why do these women go out with these men? Why are they attracted to these men? Why do they keep going back? What was she wearing at that party? What a stupid thing to do. Why was she drinking with that group of people in that hotel room? This is victim blaming, and there are numerous reasons for it, but one of them is that our cognitive structure is set up to blame victims. This is unconscious. Our cognitive structure is set up to ask questions about women and women's choices and what they are doing, thinking, and wearing. Moreover, I am not going to shout down people who ask such questions about women. They are legitimate things to ask. But let us be clear: asking questions about Mary is not going to move us anywhere in terms of preventing violence.

What we have to do is to ask a different set of questions. You can maybe see where I am going with this. The questions are not about Mary. They are about John. The questions include things like, why does John beat Mary? Why is domestic violence still a big problem in the United States and all over the world? Why do so many men abuse, physically, emotionally, verbally, and in other ways, the wom- 
en and girls, and the men and boys, that they claim to love? What is going on with men? Why do so many adult men sexually abuse little girls and little boys? Why is this a common problem in for example American society, and all over the world today? Why do we hear repeatedly about new scandals erupting in major institutions like the Catholic Church or the Penn State football program or the Boy Scouts of America, on and on and on? Then in local communities all over the country and all over the world, we hear about it all the time. The sexual abuse of children. What is going on with men? Why do so many men rape women in American society and around the world? Why do so many men rape other men? Then what is the role of the various institutions in American society that are helping to produce abusive men at pandemic rates?

Of course, this is not about individual perpetrators. That is a naive way to understanding what a much deeper and more systematic social problem is. The perpetrators are not those monsters who crawl out of the swamp and come into town and do their nasty business and then retreat into the darkness. That is a very naive notion. The perpetrators are much more normal than that, and everyday than that. So the question is, what are they doing in the American society and in the world? What are the roles of various institutions in helping to produce abusive men? What is the role of religious belief systems, the sports culture, the pornography culture, the family structure, economics, and how does this intersect, and race and ethnicity - how does that intersect? How does all this work?

Once we start making these kinds of connections and asking these important and big questions, then we can talk about how we can be transformative, or, in other words, how can we do something differently? How can we change the practices? How can we change the socialization of boys and the definitions of manhood that lead to these current outcomes? These are the kind of questions that we need to be asking and the kind of work that we need to be doing, but if we are endlessly focused on what women are doing and thinking in terms of relationships or elsewhere, we are not going to get that far.

I understand that many women who have been trying to speak out about these issues, today and yesterday, and for years and years, often are shouted down for their efforts. They are called nasty names like "male-basher" and "man-hater", or repulsive names such as "feminazi". In addition, do you know what all this is about? It is called "kill the messenger". It is because the women who are standing up and speaking out for themselves, and for other women as well as for men and boys, it is a statement to them to sit down and shut up, keep the current system in place, because we do not like it when people rock the boat. We do not like it when people challenge our power. You had better sit down and shut up. However, thank goodness these women have not done that. Thank goodness that we live in a world where there is so much women's leadership that can counteract this.

And one of the powerful roles that men can play in this work is that we can say some things that sometimes women cannot say, or, better yet, we can be heard saying some things that women often cannot be heard saying: What is a problem? It is sexism. Nevertheless, it is the truth. And so one of the things that we need to say 
is that we need more men who have the courage and the strength to start standing up and saying some of this stuff, and standing with women and not against them and pretending that somehow this is a battle between the sexes and other kinds of nonsense. We live in the world together.

Moreover, some of the rhetoric against feminists and others who have built the battered women's and rape crisis movements around the world, is that somehow, like I wrote, that they're anti-male. What about all the boys who are profoundly affected in a negative way by what some adult man is doing against their mother, themselves, their sisters? What about all those boys? What about all the young men and boys who have been traumatized by adult men's violence? The same system that produces men who abuse women produces men who abuse other men. And if we want to talk about male victims, then most male victims of violence are the victims of other men's violence. So this is something that both women and men have in common. We are both victims of men's violence. So we have it in our direct self-interest, not to mention the fact that most men that I know have women and girls that we care deeply about, in our families and our friendship circles, and every other way. So there are so many reasons why we need men to speak out. It seems obvious saying it out loud. Does it not? Now, the nature of the work that is going on in the sports culture and the U.S. military, in schools for example, has pioneered a kind of approach called the "bystander approach" to gender violence prevention. And I just want to give you the highlights of the bystander approach, because it is a big thematic shift, although there are lots of particulars, but the heart of it is, instead of seeing men as perpetrators and women as victims, or women as perpetrators, men as victims, or any combination in there, I am using the gender binary. I know there is more than men and women; there is more than male and female. And there are women who are perpetrators, and of course there are men who are victims. There is a whole spectrum. But instead of seeing it in the binary fashion, we focus on all of us as what we call bystanders, and a bystander is defined as anybody who is not a perpetrator or a victim in a given situation, so in other words friends, teammates, colleagues, coworkers, family members, those of us who are not directly involved in a dyad of abuse, but are embedded in social, family, work, school, and other peer culture relationships with people who might be in that situation. What do we do? How do we speak up? How do we challenge our friends? How do we support our friends? And how do we not remain silent in the face of abuse?

Now, when it comes to men and male culture, the goal is to get men who are not abusive to challenge men who are. And when I say abusive, I do not mean just men who are beating women. We are not just saying a man whose friend is abusing his girlfriend needs to stop the guy at the moment of attack. That is a naive way of creating a social change. It is along a continuum; we are trying to get men to interrupt each other. So, for example, if you are a guy and you are in a group of guys playing poker, talking, hanging out, no women present, and another guy says something sexist or degrading or harassing about women, instead of laughing along or pretending you did not hear it, we need men to say, "Hey, that's not 
funny. You know, that could be my sister you are talking about, and could you joke about something else? On the other hand, could you talk about something else? I don't appreciate that kind of talk". Just like if you are a white person and another white person makes a racist comment, you would hope, I hope, that white people would interrupt that racist enactment by a fellow white person. Just like with heterosexism, if you are a heterosexual person and you yourself do not enact harassing or abusive behaviors towards people of varying sexual orientations, if you do not say something in the face of other heterosexual people doing that, then, in a sense, is not your silence a form of consent and complicity?

Well, the bystander approach is trying to give people tools to interrupt that process and to speak up and to create a peer culture climate where the abusive behavior will be seen as unacceptable, not just because it is illegal, but because it is wrong and unacceptable in the peer culture. And if we can get to the place where men who act out in sexist ways will lose status, then young men and boys who act out in sexist and harassing ways towards girls and women, as well as towards other boys and men, will lose status as a result of it. We will see a radical diminution of the abuse. Because the typical perpetrator is not sick and twisted. He is a normal guy in every other way.

Among the many great things that Martin Luther King said in his life was, "In the end, what will hurt the most are not the words of our enemies but the silence of our friends". There has been an awful lot of silence in male culture about this ongoing tragedy of men's violence against women and children. In addition, all what we really need is to break that silence, and we need more men to do that.

It is easier said than done, because it is said now, but obviously it is not easy in male culture for guys to challenge each other, which is one of the reasons why part of the paradigm shift that has to happen does not just understand these issues as men's issues, but they are also leadership issues for men. Because ultimately, the responsibility for taking a stand on these issues should not fall on the shoulders of little boys or teenage boys in high school, or college age men. It should be on adult men with power. Adult men with power are the ones we need to be holding accountable for being leaders on these issues, because when somebody speaks up in a peer culture and challenges and interrupts, he or she is being a leader, really. But on a big scale, we need more adult men with power to start prioritizing these issues, and we have not seen that yet, have we?

It is an important distinction to make, because we do not need sensitivity training. But honestly we need leadership training, because, for example, when a professional coach or a manager of a baseball team or a football team makes a sexist comment, makes a homophobic statement, makes a racist comment, there will be discussions on the sports blogs and in sports talk radio. And some people will say, "Well, he needs sensitivity training". And other people will say, that's political correctness run amok, and he made a stupid statement. The real argument is he does not need sensitivity training. He needs leadership training, because he is being a bad leader, because in a society with gender diversity and sexual diversity and racial and ethnic diversity, if you make those kinds of comments, you are failing 
at your leadership. If we can make this point that was made to powerful men and women in our society at all levels of institutional authority and power, it is going to change, it is going to change the paradigm of people's thinking.

For example, the survey which has been implemented at a lot of colleges, and universities athletics activities throughout North America, showed so much about how to prevent domestic and sexual violence. There is no excuse for a college or university to not have domestic and sexual violence prevention training mandated for all student athletes, coaches, administrators, as part of their educational process (Anderson, Cooper, Okamura 2007; Baumgartner 1993; Crenshaw 2010). We know enough to know that we can easily do this. But you know what is missing? The leadership. But it is not the leadership of student athletes. It is the leadership of the athletic director, the president of the university, and the people in charge who make decisions about resources and who make decisions about priorities in the institutional settings. That is a failure, in most cases, of men's leadership.

Let us take the already mentioned Penn State as an example. Penn State is the mother of all teachable moments for the bystander approach. There were so many situations in that realm where men in powerful positions failed to act to protect children, in this case, boys. It is unbelievable but when you get into it, you realize there are pressures on men. There are constraints within peer cultures on men, which is why we need to encourage men to break through those pressures.

And one of the ways to do that is to say there is an awful lot of men who care deeply about these issues. Working with men, working with tens of thousands, hundreds of thousands of men for many decades to come would be useful and helpful to reveal the caring men on this issue, but caring deeply is not enough. We need more men with the guts, with the courage, with the strength, with the moral integrity, to break our complicit silence and challenge each other and stand with women and not against them. However, we owe it to women. There is no question about it. But we also owe it to our sons. We also owe it to young men who are growing up all over the world in situations where they did not make the choice to be a man in a culture that tells them that manhood is a certain way. They did not make the choice. We that have a choice have an opportunity and a responsibility to them as well.

Hoping that this will go forward, men and women working together, can begin the change and the transformation that will happen so that future generations will not have the level of tragedy that we deal with on a daily basis.

- Finally, the brave groups of women who dare to speak up on the ground, in country after country, should not have to wage this fight in despairing and lonely isolation. They should hear the voices of scientific thunder. You understand the connections between violence against women and vulnerability to the virus. No one can challenge your understanding (Fedler, Tanzer 2000).

- One in three women may suffer from abuse and violence in her lifetime. This is an appalling human rights violation, yet it remains one of the invisible and under-recognized pandemics of our time (Levinson 1989) 


\section{Literature}

Alvazzi del Frate A., 1998, Victims of Crime in the Developing World, United Nations Interregional Crime and Justice Research Institute, Rome.

Amnesty International, 2006, Hong Kong: Amnesty International briefing to the UN Committee on the Elimination of Discrimination against Women. Amnesty International. http://www.amnesty.org.hk/materials/HK_briefing_CEDAW_text.pdf

Anderson L., Cooper H., Okamura L., 2007, Individual differences and attitudes toward rape: A meta-analytic review, "Personality and Social Psychology Bulletin" Vol. 23.

Artz L., 1998, Access to Justice for Rural Women: Special Focus on Violence against Women, Institute of Criminology, Social Justice Resource Project, University of Cape Town. Report prepared for the Black Sash.

Bachman R., Saltzman L., 1995, Violence against women: Estimates from the redesigned survey, Research in Brief. NCJ 154348, National Institute of Justice, Washington.

Bachman R., Taylor B., 1994, The measurement of family violence and rape by the redesigned National Crime Victimization Survey, "Justice Quarterly", Vol. 11.

Bandura A., 1977, Social Learning Theory, Prentice Hall, Englewood Cliffs, NJ.

Baumgartner M.P., 2009, Violent networks: the origins and management of domestic conflict [in:] Brown L., Lamb S., Tappan M., Packaging boyhood: Saving our sons from superheroes, slackers and other media stereotypes, St. Martin's, New York.

Brownmiller S., 1975, Against Our Will: Men, Women, and Rape, Simon and Schuster, New York.

Campbell J., Garcia-Moreno C., Sharps P., 2004, Abuse during pregnancy in industrialized and developing countries, "Violence against Women”, Vol. 10.

Campbell J., 2002, Health consequences of intimate partner violence, „Lancet” Vol. 359.

Campbell J., Lewandowski L., 1997, Mental and physical health effects of intimate partner violence on women and children, „Psychiatric Clinics of North America” Vol. 20.

Clatterbaugh K., 1998, What is Problematic about Masculinities?, "Men and Masculinities” Vol. 1.

Connell R.W., Messerschmidt J.W., 2005, Hegemonic Masculinity: Rethinking the Concept, "Gender \& Society" Vol. 19.

Crenshaw K., 2010, Intersectionality and Identity Politics: Learning from Violence against Women of Color, [in:] W.K. Kolmar, F. Bartkowski (eds.), Feminist Theory: A Reader, McGraw-Hill, New York.

DeKeseredy W.S., Schwartz M.D., 2005, Masculinities and Interpersonal Violence [in:] R.W. Connell, J. Hearn, M.S. Kimmel (eds.), Handbook of Studies on Men and Masculinities, Thousand Oaks: Sage Publications.

Ellsberg M., Heise L., 2005, Researching Violence against Women: A Practical Guide for Researchers and Activists, World Health Organization, PATH, Washington DC.

Embrick D. G., Walther C.S., Wickens C.M., 2007, Working Class Masculinity: Keeping Gay Men and Lesbians out of the Workplace, "Sex Roles", Vol. 56.

Fedler J., Motara S., Webster N., 2000, beyond the facelift: The legal system's need for a change of heart, [in:] Y. Jung Park, J. Fedler, Z. Dangoor (eds.), Reclaiming Women's Spaces. New Perspectives in Violence Against Women and Sheltering in South Africa, Nisaa Institute for Women's Development, Johannesburg. 
Fedler J., Tanzer Z., 2000, A world in denial. International perspectives on violence against Women [in:] Y. Jung Park, J. Fedler, Z. Dangoor (eds.), Reclaiming Women's Spaces. New Perspectives on violence against women in South Africa, Nisaa Institute for Women's Development, Johannesburg.

Felson R., Tedeschi J., (eds.), 1993, Aggression and Violence: Social Interactionist Perspectives, American Psychological Association, Washington, DC.

Gurr T. R., 1970, Why Men Rebel, Princeton University Press, Princeton.

Katz J., 2006, The Macho Paradox: Why Some Men Hurt Women and How All Men Can Help?, Sourcebooks, Naperville.

Kaufman M., 2007, The Construction of Masculinity and the Triad of Men's Violence, [in:] L. L. O'Toole (ed.), Gender Violence: Interdisciplinary Perspectives, New University Press, New York.

Kimmel M., 2008, Contextualizing Men's Violence: The Personal Meets the Political, [in:] M. Kimmel (ed.), Guyland: The Perilous World Where Boys Become Men, Harper Collins Publishers, New York.

Levinson D., 1989, Family Violence in Cross-Cultural Perspective, Sage, Newbury Park, CA. Lewis S., 2005, Race Against Time, House of Anansi Press, Toronto.

Lusher D., Robins G., 2010, A Social Network Analysis of Hegemonic and Other Masculinities, „The Journal of Men's Studies" Vol. 18.

Messerschmidt, J.W., 2005, Men, Masculinities, and Crime [in:] R.W. Connell, J. Hearn, M.S. Kimmel (eds.), Handbook of Studies on Men and Masculinities, Sage Publications, Thousand Oaks.

Murnen S., Wright C., Kaluzny G., 2002, If 'boys will be boys', then girls will be victims? A meta-analytic review of the research that relates masculine ideology to sexual aggression, "Sex Roles" Vol. 46.

O'Toole L. L., 2007, Gender Violence in the United States, [in:] L. L. O'Toole (ed.), Gender Violence: Interdisciplinary Perspectives, New University Press, New York.

O'Toole L.L., 2007, Gender Violence: Interdisciplinary Perspectives, New University Press, New York.

Sanday P.R., 1990, Fraternity Gang Rape: Sex, Brotherhood, and Privilege on Campus, New York University Press, New York.

Schur E., 2007, Sexual Coercion in American Life, [in:] L. L. O'Toole (ed.), Gender Violence: Interdisciplinary Perspectives, New University Press, New York.

Seidler V. J., 2006, Transforming Masculinities: Men, Culture, Bodies, Power, Sex and Love, Routledge, New York.

\section{Summary}

\section{Masculinity and social violence against women}

Men's violence against women and persons of lesbian, gay, bisexual, and transgender (LGBT) identity is a phenomenon that is rarely discussed in the mainstream media except in its most horrendous and sensational forms. Even rarer is a discussion of a culture of masculinity in U.S. society, for example, that condones and in large part perpetuates men's violence against women and LGBT persons. In the media, men's violence is invisible or assumed as "natural" and thus inevitable. While the media's debate on masculinities and violence has been relatively silent or superficial, the scholarly debate on men's vi- 
olence is vibrant, and a growing men's movement is challenging misogynistic discourses and violent aspects of masculine cultures.

Keywords

masculinity, violence, women, aggression, socialization'

Proofreading: Anna Moroz-Darska

Tłumaczenie sfinansowano ze środków Ministerstwa Nauki i Szkolnictwa Wyższego na podstawie umowy nr 661/P-DUN/2018 z dnia 13 lipca 2018 roku w ramach realizacji zadania 1 - stworzenie anglojęzycznych wersji wydawanych publikacji w 2018 roku.

The translation was financed with funds made available by the Ministry of Finance and Higher Education under contract No. 661/P-DUN/2018 of 13 July 2018 as a part of the execution of task 1: the creation of English-language versions of the issued publications in 2018. 